\title{
Control of the phosphorylation of the astrocyte marker glial fibrillary acidic protein (GFAP) in the immature rat hippocampus by glutamate and calcium ions: possible key factor in astrocytic plasticity
}

R. Rodnight, C.A. Gonçalves, S.T. Wofchuk and R. Leal
Departamento de Bioquímica, Instituto de Biociências,

Universidade Federal do Rio Grande do Sul, 90046-900 Porto Alegre, RS, Brasil
Correspondence

R. Rodnight

Departamento do Bioquímica

I.B., UFRGS

Rua Sarmento Leite, 500

90046-900 Porto Alegre, RS

Brasil

Fax: 55 (051) 227-1343

Research supported by CNPq, FINEP, FAPERGS, PROPESP and the European Commission (No. Cl1*-CT94-0116).

Received November 27, 1996 Accepted January 6, 1997

\begin{abstract}
The present review describes recent research on the regulation by glutamate and $\mathrm{Ca}^{2+}$ of the phosphorylation state of the intermediate filament protein of the astrocytic cytoskeleton, glial fibrillary acidic protein (GFAP), in immature hippocampal slices. The results of this research are discussed against a background of modern knowledge of the functional importance of astrocytes in the brain and of the structure and dynamic properties of intermediate filament proteins. Astrocytes are now recognized as partners with neurons in many aspects of brain function with important roles in neural plasticity. Site-specific phosphorylation of intermediate filament proteins, including GFAP, has been shown to regulate the dynamic equilibrium between the polymerized and depolymerized state of the filaments and to play a fundamental role in mitosis. Glutamate was found to increase the phosphorylation state of GFAP in hippocampal slices from rats in the post-natal age range of 12-16 days in a reaction that was dependent on external $\mathrm{Ca}^{2+}$. The lack of external $\mathrm{Ca}^{2+}$ in the absence of glutamate also increased GFAP phosphorylation to the same extent. These effects of glutamate and $\mathrm{Ca}^{2+}$ were absent in adult hippocampal slices, where the phosphorylation of GFAP was completely $\mathrm{Ca}^{2+}$-dependent. Studies using specific agonists of glutamate receptors showed that the glutamate response was mediated by a $\mathrm{G}$ protein-linked group II metabotropic glutamate receptor (mGluR). Since group II mGluRs do not act by liberating $\mathrm{Ca}^{2+}$ from internal stores, it is proposed that activation of the receptor by glutamate inhibits $\mathrm{Ca}^{2+}$ entry into the astrocytes and consequently down-regulates a $\mathrm{Ca}^{2+}$-dependent dephosphorylation cascade regulating the phosphorylation state of GFAP. The functional significance of these results may be related to the narrow developmental window when the glutamate response is present. In the rat brain this window corresponds to the period of massive synaptogenesis during which astrocytes are known to proliferate. Possibly, glutamate liberated from developing synapses during this period may signal an increase in the phosphorylation state of GFAP and a consequent increase in the number of mitotic astrocytes.
\end{abstract}

Key words

- Astrocytes

- Glial fibrillary acidic protein

- GFAP

- Glutamate receptors

- Protein phosphorylation

- Calcium

- Intermediate filament dynamics 


\section{Introduction}

The mammalian brain contains two main groups of cells: the neurons and the neuroglia. Until recently the neuroglia were considered to play only a minor role in brain function, serving merely as a physical framework of support for neurons (the so-called "nerve glue" of Virchow, see Ref. 1). This concept has changed dramatically in the past decade: neuroglia are now recognized as partners with neurons in normal and abnormal brain function (2,3). The neuroglia belong to three main subdivisions: the oligodendrocytes, whose main function is to provide the myelin which insulates the neuronal axons; a morphologically and biochemically heterogeneous group known as the astrocytes, and the microglia which are the immune cells of the brain. Of these 3 groups the astrocytes are the most numerous and interact functionally with neurons. Astrocyte processes envelop synaptic structures forming "perineuronal nets" $(4,5)$, while other processes make intimate contact with the blood capillaries through specialized structures known as "end feet". Thus, astrocytes provide a conduit for the transport of energy from the blood stream to the nerve terminals and recent work has demonstrated a tight coupling between synaptic activity and the uptake of glucose by the astrocytic "end feet" (6). Interestingly, astrocytes first metabolize glucose to lactate before supplying it as energy to neurons. Further astrocytes modulate the transmission of synaptic signals by the uptake of $\mathrm{K}^{+}$and neurotransmitters (79). Depending on cell type, developmental stage and brain area, glial cells, and especially astrocytes, express many receptors (10-15) and ion channels $(16,17)$ found in neurons. These cells also secrete factors which regulate the growth of neurons (18). Conversely, there is evidence that glutamate released from synapses regulates glial proliferation and differentiation (19). Direct signalling from astrocytes to neurons via glutamate-mediated calcium waves has been described (20-23) as also have acute effects of neuronal activity on the morphology of astrocytes (24) or of perisynaptic Schwann cells in the frog neuromuscular junction (25).

Astrocytes are believed to play a fundamental role in the modelling of the nervous system during ontogeny $(26,27)$. Experiencedependent plasticity of astrocytes has been studied in experimental approaches that embrace models involving modification of astrocyte structure and function such as darkrearing (28), hippocampal kindling $(29,30)$, spreading depression $(31,32)$, rearing in complex environments (33), and long-term potentiation $(34,35)$. Astrocytes also exhibit plastic changes in response to cerebral injury (36), electroconvulsive seizures (37) and the administration of psychotropic drugs (38). Moreover, transplants of astrocytes alleviate memory deficits induced by lesions in cholinergic pathways in the rat hippocampus (39).

In this review we focus on factors regulating the phosphorylation state of glial fibrillary acidic protein (GFAP) in immature astrocytes. This cytoskeletal glial protein is expressed mainly in astrocytes and is a valuable marker for these cells since it is absent in neurons (40). GFAP is a class III intermediate filament (IF) protein which exhibits dynamic properties similar to those of other members of this class of proteins. These dynamic properties of GFAP are modulated by phosphorylation and play a fundamental role in astrocytic plasticity. We will first discuss briefly the background to present knowledge of the structure and general dynamic properties of IF proteins.

\section{Intermediate filament proteins - struc- ture and dynamic properties}

The structure of GFAP is schematically illustrated in Figure 1. Like all class III IF proteins, GFAP consists of an $\alpha$-helical rod domain flanked by a non-helical $\mathrm{N}$-terminal head and a C-terminal tail. The central rod domain is highly invariant in its residues with 
at least $70 \%$ homology between class III IF proteins $(41,42)$ and consists of four tracts (1A, 1B, 2A and 2B) of repetitive heptads, where residues a and d generally have high hydropathy and form a hydrophobic line along the helical structure that allows a fit between two helical chains. There are three non-helical segments linking these tracts. All type III IF proteins possess a highly charged N-terminal segment which, in the case of GFAP, incorporates 5 phosphorylation sites. Between the N-terminal segment and the rod domain there is a well-conserved segment named $\mathrm{H} 1$. All IF proteins possess a well-conserved nonhelical C-terminal segment which is not charged in type III IF proteins. In porcine but not in rat GFAP this segment is phosphorylated at a single serine residue.

The assembly of IF proteins involves several steps (Figure 1). First a dimer is formed between two parallel monomers; next antiparallel dimers interact through residues in their coiled-coil 1B segment forming a tetramer or protofilament, and then the protofilaments interact through residues in the coiled-coil 2B segments to form an octamer. These structures were identified in desmin filaments by chemical crosslinking (43). In the case of GFAP, a study of the selfassembly of mutants of this protein showed

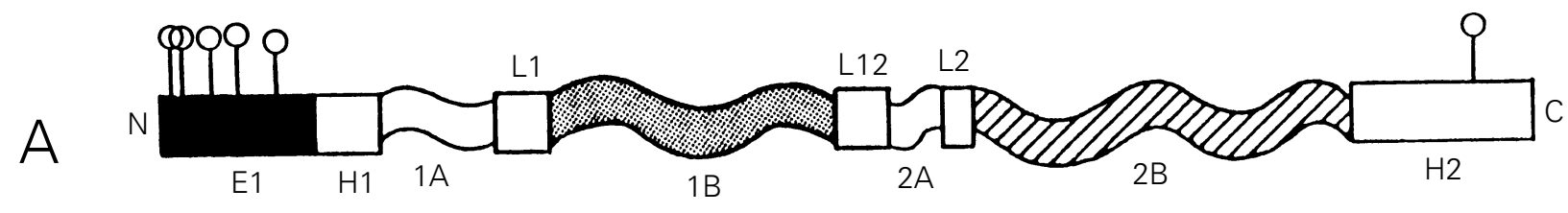

B

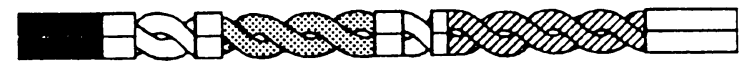

C

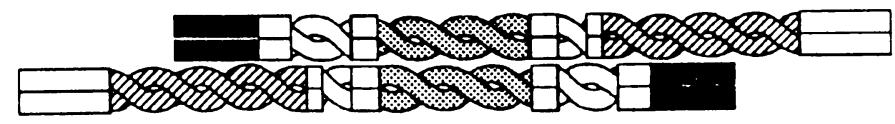

D

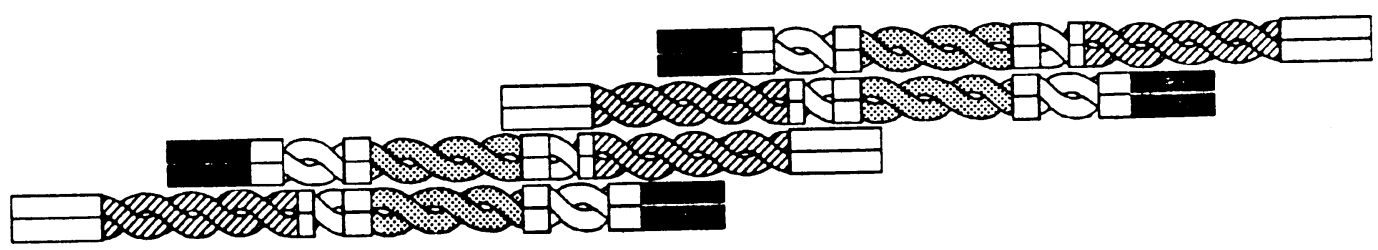

Figure 1 - Schematic illustration of the filamentous structure of GFAP. A, Structure of the monomer. Five phosphorylation sites are shown in segment $\mathrm{E} 1$ in the $\mathrm{N}$-terminal domain and one in segment $\mathrm{H} 2$ at the $\mathrm{C}$-terminal (see Figure 2). The rod domain comprises four helicoidal segments (1A, 1B, 2A and 2B) and three linkers (L1, L2 and L12). B, Structure of the dimer. Parallel monomers interact to form coiled-coil arrangements in the central domain. $C$, Structure of the tetramer or protofilament. Anti-parallel dimers interact through residues in the coiled coil. D, Structure of the octamer. Tetramers interact through residues in coiled-coil 2B. Adapted from Refs. 41-43. See text for details. 
that the sequence KLLEGEE in tract $2 \mathrm{~B}$ as well as the entire head domain is essential (44).

In in vitro experiments the assembly state of purified GFAP is influenced by the ionic strength and $\mathrm{pH}$ of the medium, the presence of $\mathrm{Mg}^{2+}$ and $\mathrm{Ca}^{2+}(45,46)$ and especially (as discussed below) by the phoshorylation state of the protein (47). Phosphorylation is also important in the intact cell, particularly in preparing the cytoskeleton for cell division. However, the exact mechanism of IF assembly/disassembly in vivo is unknown. Simple self-assembly is unlikely and it is probable that other factors are needed as well as regulatory phosphorylation. A chaperone-like activity modulating GFAP and vimentin assembly has been described (48). Moreover, S100ß, a $\mathrm{Ca}^{2+}$-binding protein expressed in astrocytes, may be involved in glial filament formation (49). Another interesting fact is that in immature or injured astrocytes GFAP can coassemble with vimentin, a process that is dependent on the KLLEGEE sequence mentioned above (44).

Intermediate filaments, in contrast to microtubules and actin filaments, have no polarity, and it is not possible to identify a vectorial array of protofilaments. Filaments are assembled or incorporated into preformed filaments uniformly throughout the cytoplasm and an apparent polar or vectorial incorporation (from the perinuclear region to the cell periphery) may be the consequence of a nonuniform distribution of these filaments $(50,51)$.

\section{General and functional aspects of GFAP phosphorylation}

It has been known for some years that IF proteins, including GFAP, undergo cyclic phosphorylation and dephosphorylation in intact cell preparations $(52,53)$, but until recently information on the sites phosphorylated was lacking. These sites have now been described for porcine GFAP phosphorylated in vitro where six sites were identified by Japanese workers $(47,54)$. Five of these sites are located in the $\mathrm{N}$-terminal head domain (Thr7, Ser8, Ser13, Ser17, Ser34) and one in the tail domain (Ser389) where they are phosphorylated by cyclic AMP-dependent protein kinase (PKA), $\mathrm{Ca}^{2+} /$ calmodulin-dependent kinase II (CaMK II), protein kinase C (PKC) and the cdc-2 kinase. The phosphorylation sites in rat GFAP are not known but the sequence homology between porcine and rat GFAP in the N-terminal domain (55) is sufficient to assume that the corresponding consensus sequences in rat GFAP are potential phosphorylation sites and targets for PKA, PKC, CaMK II and the cdc-2 kinase (Figure 2). Less is known about the sites and kinases involved in GFAP phosphorylation in intact cell systems, but a start has been made. Japanese workers used monoclonal antibodies recognizing specific phosphorylation sites and immunofluorescence to demonstrate that one threonine and three serines in the head region of GFAP are phosphorylated in vivo at different stages of the cell cycle (56-58). With regard to the kinases responsible for these in vivo phosphorylations, present evidence points to the direct or indirect participation of PKA, CaMK II, the cdc-2 kinase and an unknown kinase (CF kinase) (58). In our laboratory we have used tryptic phosphopeptide mapping of ${ }^{32} \mathrm{P}$-labelled GFAP extracted from incubated hippocampal slices in attempts to identify the kinases involved. Our results suggest that CaMK II and PKA are the main kinases involved, either directly or indirectly, in GFAP phosphorylation in this preparation (59 and Leal R, Gonçalves CA and Rodnight $\mathrm{R}$, unpublished data). Phosphorylation of GFAP in primary astrocyte cultures by CaMK II has been reported (60).

As mentioned above, the phosphorylation of IF proteins is an important factor in regulating the dynamic equilibrium between polymerized and depolymerized GFAP. Phosphorylation of disassembled subunits inhibits their assembly into filaments $(47,61)$, with 


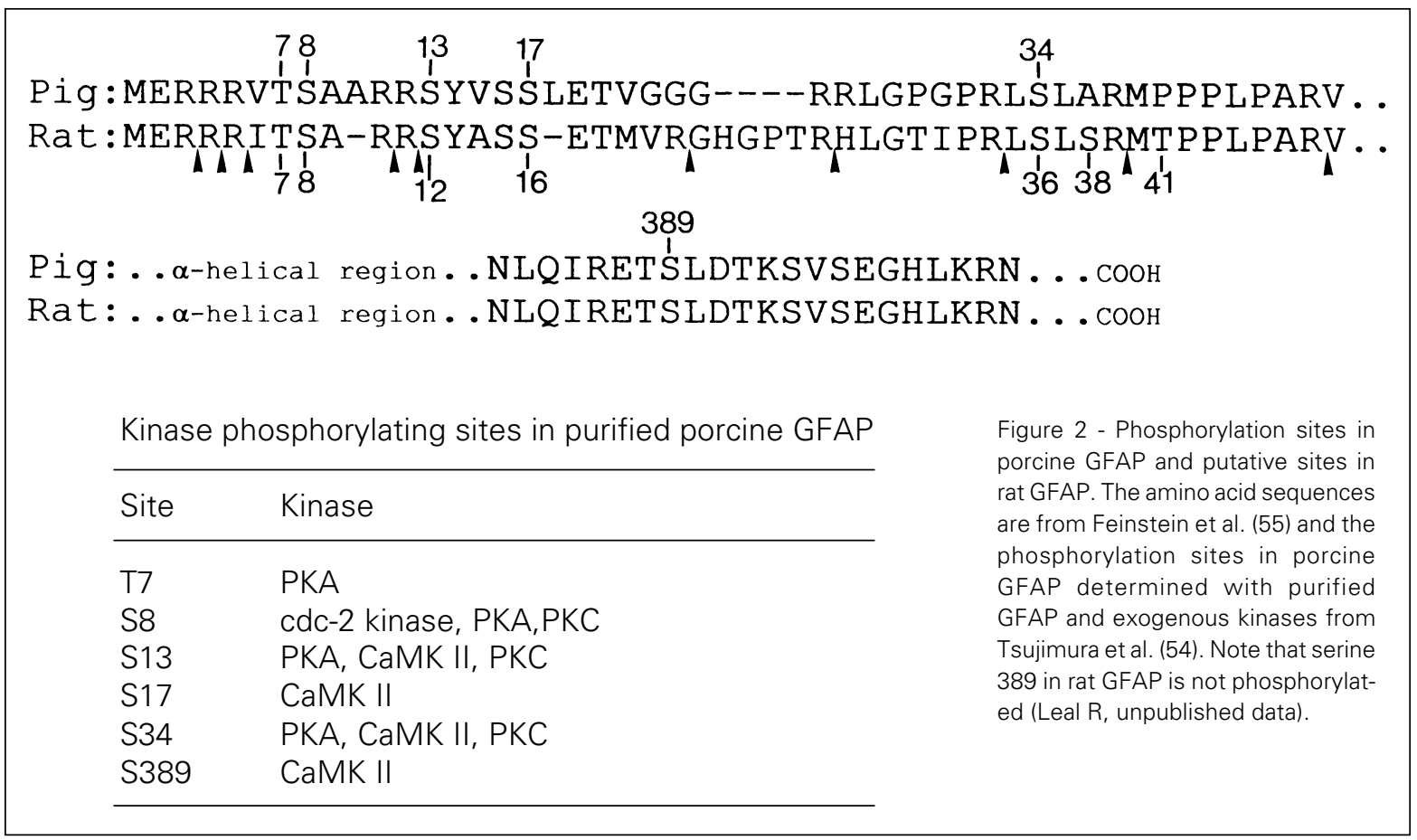

subunit exchange in the case of GFAP being suppressed in proportion to the extent of phosphorylation(62). Moreover, IF protein phosphorylation plays a crucial role in dividing cells, where evidence from cell cultures has shown that the disassembly of the cytoskeleton preceding mitosis in some cells is regulated by a site-specific increase in the phosphorylation state of vimentin and GFAP (57,63-65). In interphase cells changes in the phosphorylation state of IF proteins may have profound effects on the structure of the cytoskeleton, as shown by studies in which hyperphosphorylation of vimentin induced by protein phosphatase inhibitors $(66,67)$ or the antitumor drug fostriecin (68) was associated with intermediate filament reorganization.

\section{Glutamate agonists and external $\mathrm{Ca}^{2+}$ lack increase the phosphorylation state of GFAP in immature slices from the rat hippocampus}

Our interest in this area arose from a chance observation while using two-dimensional electrophoresis to study the regulation by glutamate of the phosphorylation of PKC substrates in hippocampal slices from immature rats (post-natal days 12-16) labelled with [32P]phosphate. We observed a weak stimulation of the PKC substrates and a much stronger stimulation of an unknown protein, designated pp-H47 (69), which was subsequently identified as GFAP (70).

Glutamate receptors are classified into ionotropic (consisting of ligand-gated ion channels) and metabotropic (coupled to second-messenger systems) (71) receptors. The effect of glutamate on GFAP phosphorylation was shown to occur via a metabotropic receptor since the highly selective metabotropic glutamate agonist, (1S,3R)-1-aminocyclopentane-1,3-dicarboxylic acid (1S,3RACPD), stimulated the reaction to the same extent as glutamate, while agonists of ionotropic glutamate receptors were ineffective (72). This effect was shown to occur via a $G$ protein since the stimulation was inhibited by pertussis toxin. Half maximal stimulation was achieved with $20 \mu \mathrm{M}$ 1S,3R-ACPD. A typical autoradiograph illustrating the effect of glutamate and 1S,3R-ACPD on GFAP 
phosphorylation is shown in Figure 3.

The glutamate response was only observed in the presence of $\mathrm{Ca}^{2+}$ in the medium and was absent in slices prepared from adult hippocampus. At first, this need for $\mathrm{Ca}^{2+}$ was not surprising since we had previously observed that the basal phosphorylation of GFAP in adult slices is completely dependent on external $\mathrm{Ca}^{2+}$. However, in immature slices we later found that external $\mathrm{Ca}^{2+}$ partially inhibits the incorporation of $\left.{ }^{32} \mathrm{P}\right]$ phosphate into GFAP (73). This inhibition starts at a low $\mathrm{Ca}^{2+}$ concentration and reaches a plateau of about $50 \%$ inhibition at $1 \mathrm{mM} \mathrm{Ca}^{2+}$. During the subsequent ontogenetic development the phosphorylation system gradually becomes dependent on external $\mathrm{Ca}^{2+}$ (Figure 4). For these contrasting effects of $\mathrm{Ca}^{2+}$ on GFAP phosphorylation to occur the cation has to cross the cell membrane. This was shown by the use of $\mathrm{Ca}^{2+}$ channel blockers, which in the presence of external $\mathrm{Ca}^{2+}$ increased GFAP phosphorylation in immature slices and inhibited it in adult slices (73). Furthermore, the rates of GFAP phosphorylation in immature slices in the absence of external $\mathrm{Ca}^{2+}$ com- pared with those obtained in the presence of glutamate plus $\mathrm{Ca}^{2+}$ were found to be equal (Figure 5). Moreover, the effects of $\mathrm{Ca}^{2+}$-lack and $\mathrm{Ca}^{2+}$-lack plus glutamate were also not significantly different. These results suggest that glutamate was acting through an unknown mechanism to reverse the inhibitory effect of $\mathrm{Ca}^{2+}$ on the phosphorylation reaction.

\section{Nature of the astrocytic metabotropic glutamate receptor involved in the control of GFAP phosphorylation in immature slices}

Both ionotropic (iGluRs) and metabotropic glutamate receptors (mGluRs) have been demonstrated in astrocytes in culture and in immature and adult glia in situ (12,74-76). Of the iGluRs only two of the three main subgroups, defined by their agonist sensitivity to (RS)- $\alpha$-amino-3-hydroxy-5-methyl-4isoxazolepropionic acid (AMPA) and kainic acid (KA), are expressed in astrocytes. Functional receptors of the third group, which are activated by $\mathrm{N}$-methyl-D-aspartic acid (NMDA), have not been detected in these
Figure 3 - Autoradiographs illustrating the stimulation of GFAP phosphorylation by $1 \mathrm{mM}$ glutamate (A and $B$ ) and $100 \mu \mathrm{M}$ 1S,3R-ACPD ( $C$ and $D)$, where $A$ and $C$ are from control incubations and $B$ and $D$ are from incubations in the presence of the agonist. Hippocampal slices from 15-day old rats were labelled with [32P]phosphate and analyzed by non-equilibrium $\mathrm{pH}$ gradient electrophoresis (NEPHGE) for the first dimension and PAGE electrophoresis on $8 \%$ gels for the second dimension. To minimize intergel variation two first dimension rod gels (control and test) were mounted as mirror images on a single second dimension slab gel. Arrows point to GFAP. Reproduced, with permission, from Ref. 72.

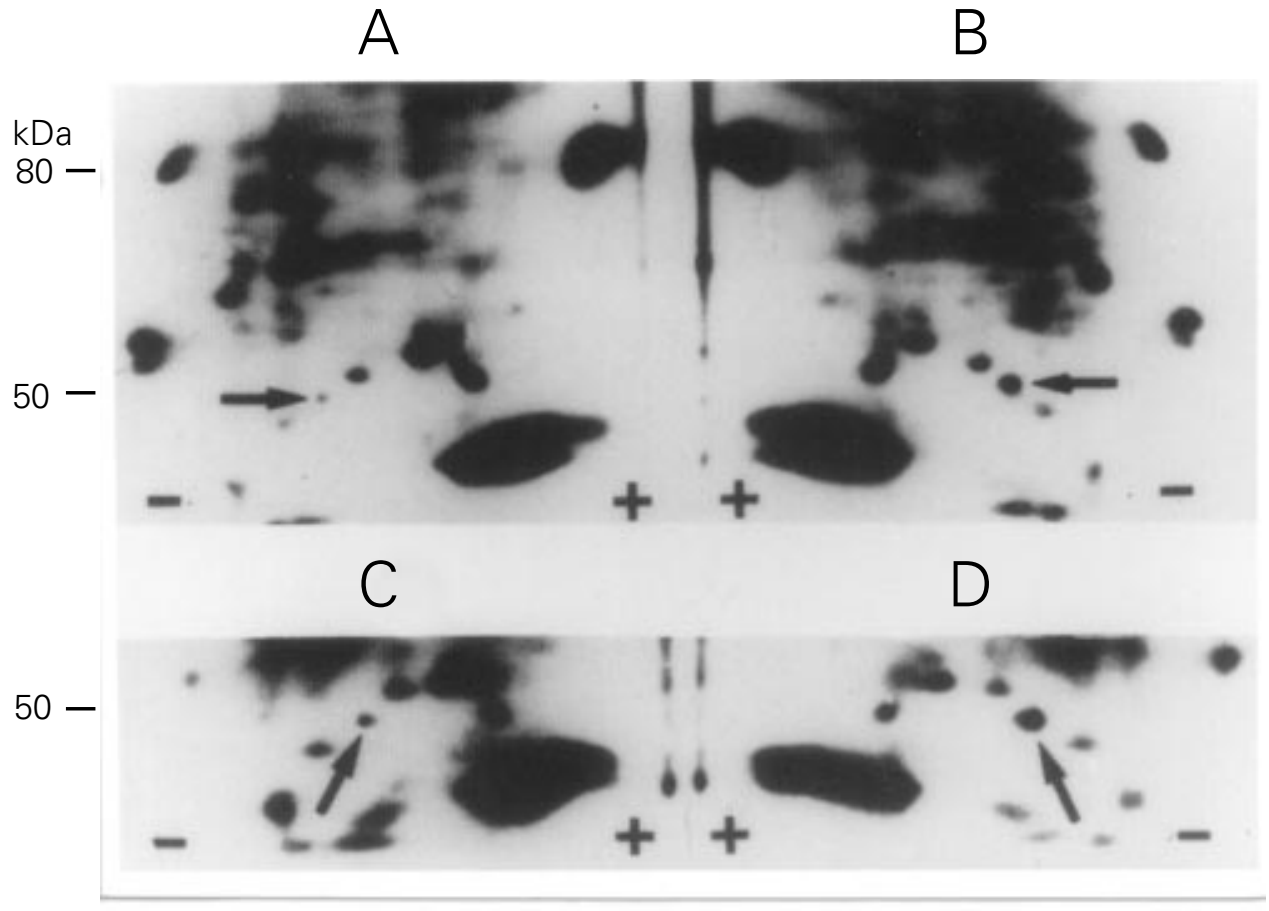


cells, although they may express non-functional subunits of this receptor (77).

The family of mGluRs comprises 8 subtypes divided into three groups according to the extent of amino acid homology, agonist sensitivity and associated signal transduction mechanisms (78). All mGluRs are coupled to $\mathrm{G}$ proteins and either regulate the hydrolysis of phosphoinositides (group I, mGluRs1,5) or the synthesis of cyclic AMP (group II, mGluRs2,3, and group III, mGluRs4,6-8) (Table 1). Agonists of mGluRs include the highly selective 1S,3R-ACPD, and L(+)-2amino-4-phosphonobutyric acid (L-AP4) and the mixed agonists quisqualate and ibotenate. Quisqualate exhibits preference for group I, 1S,3R-ACPD for group II and L-AP4 for group III (Table 1; Refs. 79-81).

Two mGluR subtypes have been unequivocally detected in astrocytes. One of them is a group I receptor since specific mGluR agonists release $\mathrm{Ca}^{2+}$ from internal stores in astrocyte cultures (82) and in astrocytes of hippocampal slices in situ $(23,83)$ through the hydrolysis of phosphatidylinositol and the generation of the $\mathrm{Ca}^{2+}$-releasing agent inositol trisphosphate (IP3). This response is apparently due to mGluR5 since high immunoreactivity to this receptor was demonstrated in hippocampal astrocytes in situ (84). The other receptor belongs to group II and has been tentatively identified as mGluR3. Antibody immunocytochemistry and in situ hybridization for this mGluR showed that it is abundantly expressed in glial cells (85).

Our evidence strongly points to mGluR3 as the receptor responsible for the control of GFAP phosphorylation in immature slices. In a study on the efficacy of a series of mGluR agonists we found that $1 \mathrm{~S}, 3 \mathrm{R}-\mathrm{ACPD}$ was significantly $(\mathrm{P}<0.01)$ more effective than quisqualate in stimulating phosphorylation, suggesting a group II receptor which, from the immunocytochemical evidence cited above, is most likely to be mGluR3 (Wofchuk ST and

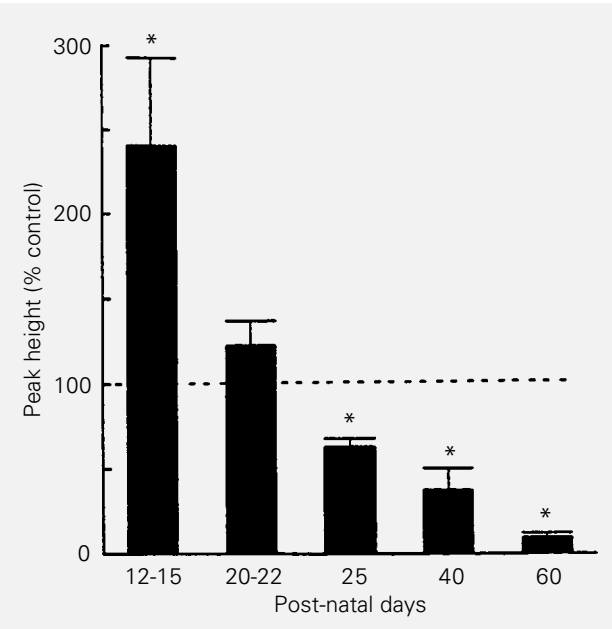

Figure 4 - Developmental profile of the sensitivity of GFAP phosphorylation in incubated hippocampal slices to external $\mathrm{Ca}^{2+}$. Each bar represents the percentage change $( \pm$ SEM) in GFAP phosphorylation in media lacking $\mathrm{Ca}^{2+}$ from phosphorylation in media containing $1 \mathrm{mM}$ $\mathrm{Ca}^{2+}$ (indicated by the dotted line). ${ }^{*} P<0.01$ compared to control (paired $t$-test). Reproduced, with permission, from Ref. 73.

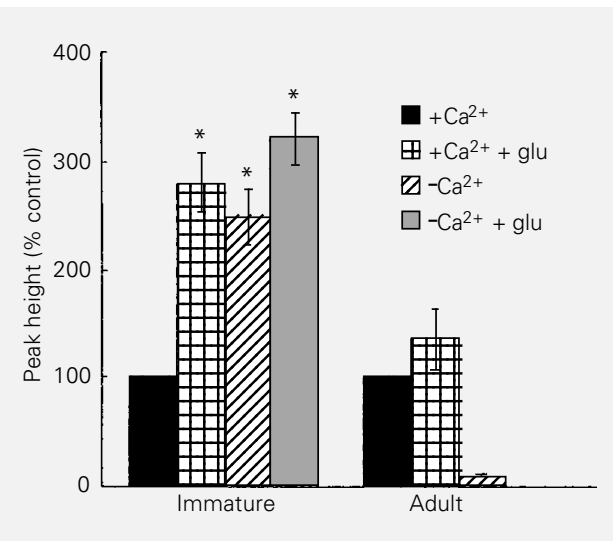

Rodnight R, unpublished data). However, this result does not exclude the contribution of a group I receptor since quisqualate was only $22 \%$ less effective than 1S,3R-ACPD. We therefore tested the effect of an inhibitor of phosphatidylinositol-specific phospholipase $\mathrm{C}$, the aminosteroid U73122 (86). This compound had no effect on the stimulation of GFAP phosphorylation by $1 \mathrm{~S}, 3 \mathrm{R}-\mathrm{ACPD}$, although it effectively inhibited the generation of inositol phosphates from glutamate-stimulated phosphatidylinositol hydrolysis in astrocyte cultures. This result makes less likely the contribution of a group I mGluR to the phosphorylation response. Finally, group III mGluRs were excluded by showing that LAP4 did not stimulate GFAP phosphorylation.
Figure 5 - Comparison of the effect of glutamate (glu) and $\mathrm{Ca}^{2+}$ on GFAP phosphorylation in hippocampal slices from immature and adult tissue. In the immature block the three columns marked by an asterisk are significantly different from the $100 \%$ control, but do not differ significantly one from another. Each block is the mean of 6-9 observations. Note that in the adult hippocampus glutamate had no effect on GFAP phosphorylation, which at this age was completely dependent on external $\mathrm{Ca}^{2+}$. ${ }^{*} \mathrm{P}<0.001$ (paired $t$-test) Modified, with permission, from Ref. 72 
Table 1 - Some characteristics of metabotropic glutamate receptors.

${ }^{*}$ Several splice variants known. ${ }^{* *}$ In adult brain slices (115) or expressed in Chinese hamster ovary cells (81). Activation of these receptors inhibits forskolin-stimulated adenylyl cyclase activity, while in immature brain slices they increase basal and forskolin-stimulated cyclic AMP synthesis (116). PI, Phosphatidylinositol; L-SOP, L-serine-O-phosphate. For complete descriptions of mGluRs, see Refs. 71,117-119.

\begin{tabular}{|c|c|c|}
\hline \multicolumn{2}{|l|}{ Receptors } & \multirow{2}{*}{$\begin{array}{l}\text { Characteristics } \\
\text { Increases PI hydrolysis } \\
\text { Quisqualate }>\text { glu>>ibotenate }>1 \text { S,3R-ACPD } \\
\text { Expressed in neurons }\end{array}$} \\
\hline Group I & mGluR $1^{*}$ & \\
\hline & mGluR5 & $\begin{array}{l}\text { Increases PI hydrolysis } \\
\text { Quisqualate>glu }>>\text { ibotenate }>1 \text { S,3R-ACPD } \\
\text { Expressed in neurons and glia }\end{array}$ \\
\hline \multirow[t]{2}{*}{ Group II } & mGluR2 & $\begin{array}{l}\text { Regulates }{ }^{* *} \text { cyclic AMP synthesis } \\
\text { 1S,3R-ACPD>ibotenate>quisqualate } \\
\text { Expressed in neurons; ? in glia }\end{array}$ \\
\hline & mGluR3 & $\begin{array}{l}\text { Regulates }{ }^{* *} \text { cyclic AMP synthesis } \\
\text { 1S,3R-ACPD>ibotenate>quisqualate } \\
\text { Expressed in glia and neurons }\end{array}$ \\
\hline \multirow[t]{4}{*}{ Group III } & mGluR4 & $\begin{array}{l}\text { Regulates cyclic AMP synthesis } \\
\text { L-AP4 = L-SOP>ibotenate } \\
\text { Expressed in neurons }\end{array}$ \\
\hline & mGluR6 & $\begin{array}{l}\text { Regulates cyclic AMP synthesis } \\
\text { L-AP4 } \\
\text { Expressed in retina }\end{array}$ \\
\hline & mGluR7 & $\begin{array}{l}\text { Regulates cyclic AMP synthesis } \\
\text { L-AP4 } \\
\text { Expressed in neurons }\end{array}$ \\
\hline & mGluR8 & $\begin{array}{l}\text { Regulates cyclic AMP synthesis } \\
\text { L-AP4 } \\
\text { Expressed in retina }\end{array}$ \\
\hline
\end{tabular}

\section{What is the role of external $\mathrm{Ca}^{2+}$ ?}

Membrane exchange of $\mathrm{Ca}^{2+}$ in mammalian cells under basal conditions occurs via tonically active voltage-dependent channels, a plasma membrane $\mathrm{Ca}^{2+}$-ATPase and $\mathrm{Na}^{+} /$ $\mathrm{Ca}^{2+}$ exchange (87). Voltage-dependent $\mathrm{Ca}^{2+}$ channels of the $\mathrm{T}$ and $\mathrm{L}$ types have been identified in astrocytes (87). Our evidence suggests that in immature hippocampal slices $\mathrm{Ca}^{2+}$ enters astrocytes through tonically active L-type channels, since entry (measured by a decrease in GFAP phosphorylation) was blocked by the L-type channel antagonist nifedipine (73).
Primary cultures of astrocytes and astrocytes in situ (e.g., in hippocampal slices) express neurotransmitter receptors that trigger increases in internal $\mathrm{Ca}^{2+}$. These receptors include glutamate receptors $(23,83,88-91)$ and $\alpha_{1}$-adrenergic receptors (92). Increases in internal $\mathrm{Ca}^{2+}$ due to glutamate may be due to the activation of ionotropic receptors and $\mathrm{Ca}^{2+}$ entry through a receptor channel or voltage-dependent channels, or activation of metabotropic receptors and the release of $\mathrm{Ca}^{2+}$ from internal stores. In either case the $\mathrm{Ca}^{2+}$ signal is propagated to adjacent cells through gap junctions in the form of waves $(90,91,93$ 95). As already mentioned, these glial calcium waves when initiated by glutamate released from neurons may constitute a mechanism for glia-to-neuron communication (2022,96).

We initially considered that the $\mathrm{Ca}^{2+} \mathrm{de}-$ pendence of the stimulation of GFAP phosphorylation by glutamate might be due to an activating effect of the cation on the receptor. We viewed the receptor as one that either permitted $\mathrm{Ca}^{2+}$ entry (i.e., ionotropic) or activated the release of $\mathrm{Ca}^{2+}$ from internal stores (i.e., metabotropic). The increase in internal $\mathrm{Ca}^{2+}$ was postulated to stimulate a $\mathrm{Ca}^{2+}$-dependent kinase associated with GFAP. This hypothesis was discredited when we discovered that 1) external $\mathrm{Ca}^{2+}$ inhibited the basal incorporation of $\left[{ }^{32} \mathrm{P}\right]$ phosphate into GFAP and that 2) the stimulation by glutamate is mediated by a group II mGluR which does not release internal $\mathrm{Ca}^{2+}$. The mechanism by which glutamate reverses the inhibitory effect of $\mathrm{Ca}^{2+}$ on the reaction is uncertain, but is probably related to an inhibition of $\mathrm{Ca}^{2+}$ entry through L-type channels. The inhibition of ion channels by $\mathrm{G}$ protein activation is a wellestablished phenomenon $(97,98)$ and recent studies have demonstrated a $\mathrm{G}$ protein-mediated inhibition of $\mathrm{Ca}^{2+}$ currents through neuronal L-type channels by stimulation of group II mGluRs $(99,100)$. Channel inhibition of this type is generally considered to be membrane delimited and independent of second 
messenger events involving cyclic AMP or PKC. Recent evidence suggests a direct effect on the channel due to diffusion of $\beta \gamma$ subunits released from the activated $\mathrm{G}$ protein heterotrimer (101).

The exact mechanism of the inhibitory effect of external $\mathrm{Ca}^{2+}$ on basal GFAP phosphorylation is unknown, but is unlikely to be due to inhibition of a protein kinase; indeed the main two kinases phosphorylating GFAP in immature slices in the absence of $\mathrm{Ca}^{2+}$ appear to be CaMK and PKA (59 and Leal R, Gonçalves CA and Rodnight R, unpublished data). A more viable hypothesis proposes that external $\mathrm{Ca}^{2+}$ stimulates a $\mathrm{Ca}^{2+}$-dependent dephosphorylation event associated with GFAP, thus changing the dynamic equilibrium between phosphorylation and dephosphorylation and reducing the steady-state level of phosphate in the protein. These considerations led us to conduct a study on the enzymes involved in the dephosphorylation of GFAP.

\section{Dephosphorylation of GFAP}

Serine/threonine protein phosphatases (PPs) are classified into four groups designated types PP1, PP2A, PP2B and PP2C (102). The activities of PP1 and PP2A are cationindependent, whereas that of PP2B (generally known as calcineurin) is dependent on $\mathrm{Ca}^{2+}$ and calmodulin and that of PP2C on $\mathrm{Mg}^{2+}$. By using the specific inhibitors of PP1 and PP2A, okadaic acid and microcystin-LR, respectively, we showed that in cytoskeletal preparations and immature hippocampal slices the dephosphorylation of GFAP is catalyzed by PP1 (103). No evidence for a direct $\mathrm{Ca}^{2+}$-dependent dephosphorylation of GFAP was found in this study. However, a highly specific inhibitor of calcineurin, the immunosuppressant FK506 (104), increased GFAP phosphorylation in immature slices and astrocyte cultures in the presence of $\mathrm{Ca}^{2+}$, i.e., the drug reversed the inhibitory effect of external $\mathrm{Ca}^{2+}$ on the phosphorylation reaction
(Vinadé L and Rodnight R, unpublished data). This result strongly suggested the presence of calcineurin associated with GFAP in astrocytes, a somewhat surprising conclusion since several studies had failed to demonstrate the occurrence of the enzyme in glia by immunocytochemistry $(105,106)$. However, we were able to confirm the FK506 result by immunoblotting using a monoclonal antibody to the Bsubunit of calcineurin. Applied to extracts of primary cultures of astrocytes the antibody revealed a low calcineurin content equivalent to one fiftieth of the content in hippocampal tissue (Vinadé L and Rodnight R, unpublished data). These data strongly suggest that calcineurin plays a role in the dephosphorylation of GFAP. Since we found no evidence for a direct $\mathrm{Ca}^{2+}$-dependent dephosphorylation of GFAP sites, the action of calcineurin probably occurs via the $\mathrm{Ca}^{2+}$-dependent enzyme cascade which is known to regulate PP1 in many tissues and which is involved in the phenomenon of long-term depression (107). This cascade depends on the fact that in many cells type 1 phosphatases are inhibited by the phosphorylated form of the protein inhibitor1 (108), which in turn is dephosphorylated (and inactivated) by calcineurin. Thus, downregulation of calcineurin through inhibition of $\mathrm{Ca}^{2+}$ entry or lack of external $\mathrm{Ca}^{2+}$ would increase the inhibition by phospho-inhibitor1 of the type 1 phosphatase associated with GFAP.

\section{Discussion: hypothesis and perspectives}

A hypothetical scheme to explain the action of glutamate agonists on the $\mathrm{Ca}^{2+}$-dependent phosphorylation of GFAP in immature slices is shown in Figure 6. The scheme postulates that the activation of metabotropic glutamate receptors of the mGluR3 subtype inhibits L-type $\mathrm{Ca}^{2+}$ channels and consequently down-regulates the $\mathrm{Ca}^{2+}$-dependent dephosphorylation of a putative inhibitor-1 protein, thus increasing the inhibition of PP1 
Figure 6 - Hypothetical scheme to explain the $\mathrm{Ca}^{2+}$-dependent action of glutamate in regulating the phosphorylation of GFAP in immature hippocampal slices. Phosphorylation sites in a filament of GFAP are represented by the encircled ' $P$ ' and are shown associated with CaMK activity, PKA and protein phosphatase PP1. The scheme proposes that activation of a metabotropic receptor of subtype mGluR3 by glutamate inhibits the entry of $\mathrm{Ca}^{2+}$ through $\mathrm{Ca}^{2+}$ channels. The consequent decrease in internal $\mathrm{Ca}^{2+}$ downregulates the protein phosphatase calcineurin and thus increases the phosphorylation state of a putative inhibitor-1 protein. Since phosho-inhibitor-1, in contrast to dephospho-inhibitor1, inhibits PP1 (108) the phosphorylation state of GFAP is increased.

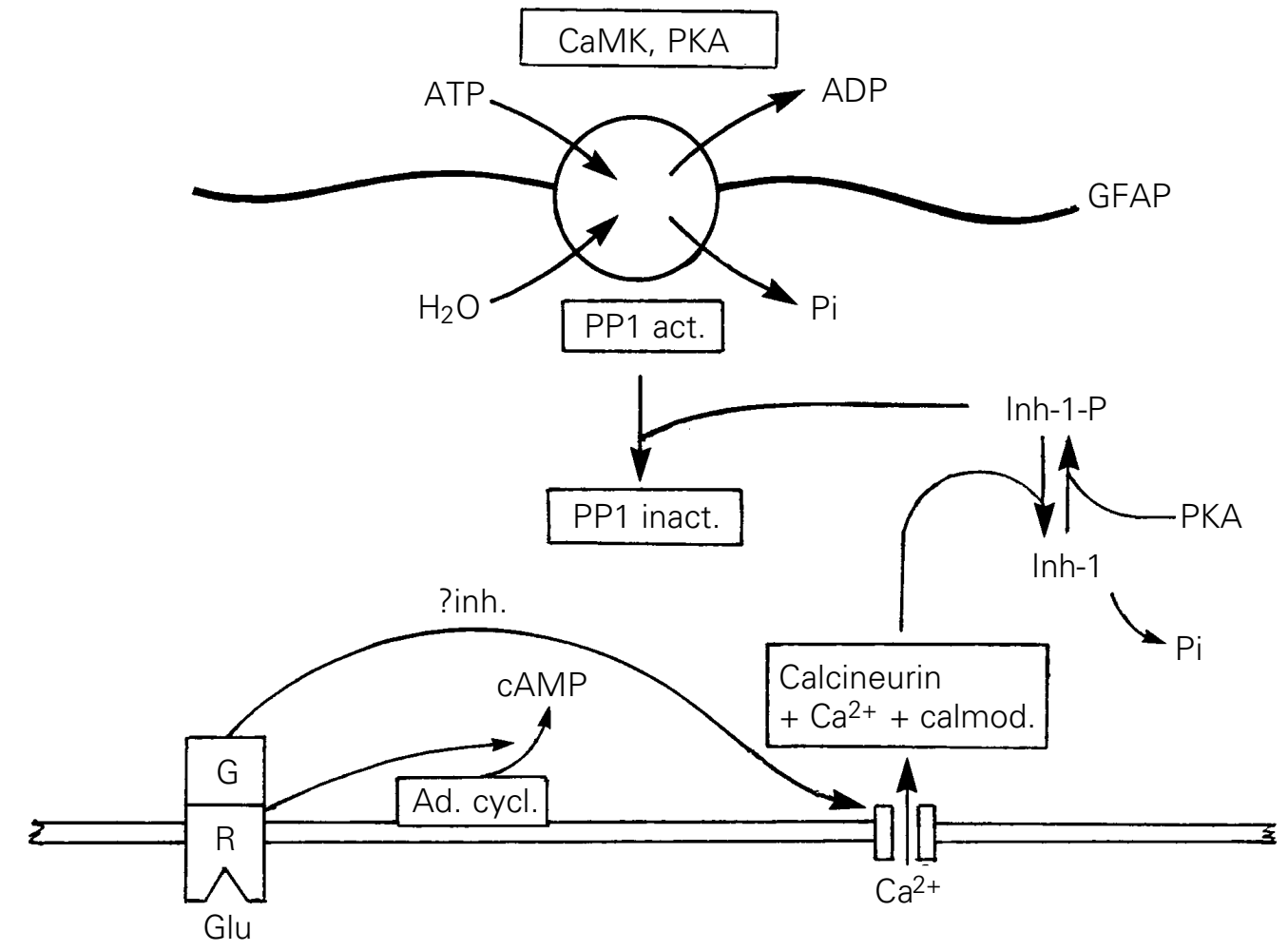

and the phosphorylation state of GFAP. Note that even though one of the kinases associated with GFAP is a $\mathrm{Ca}^{2+} /$ calmodulin-dependent enzyme, no effect of glutamate stimulation on the phosphorylation of GFAP is postulated since the activation of mGluR3 does not increase internal $\mathrm{Ca}^{2+}$. Basal CaMK activity might be due to a discrete pool of internal $\mathrm{Ca}^{2+}$ or to the activity of autophosphorylated CaMK II which does not require $\mathrm{Ca}^{2+}(109)$. We are inclined to favor the latter interpretation since autophosphorylated CaMK II has been reported to occur in astrocyte cultures (60). It is also necessary to point out that the scheme does not take into account the dynamic nature of the turnover of protein phosphate in GFAP. While phosphorylation of residues is considered to occur on the intact filaments, the substrates of the dephosphorylation reaction are presumably disassembled subunits (dimers or tetramers).

A necessary condition of the mechanism depicted in Figure 6 is the existence of closed intracellular compartments containing group
II receptors, $\mathrm{Ca}^{2+}$ channels and the enzymes involved in GFAP phosphorylation, to which internal $\mathrm{Ca}^{2+}$ modulated by group I glutamate and other neurotransmitter receptors is inaccessible. Indeed membrane-delimited control of $\mathrm{Ca}^{2+}$ entry by $\mathrm{G}$ protein subunits would require the receptors and channels to occur in close proximity. It is tempting to speculate that such compartmentation occurs principally in astrocyte processes where the GFAP filaments are situated close to the plasma membrane. Immature astrocytes in the rat hippocampus possess extensive processes (110) and depolymerization of their filaments can be envisaged as a prerequisite to the rounding up of the cells prior to mitosis. Localized $\mathrm{Ca}^{2+}$ signalling has been proposed to explain the spatially separated phosphorylation of vimentin by CaMK II in astrocytes (58).

Future work in this area will involve attempts to demonstrate aspects of the scheme in Figure 6 which remain uncertain. These are: 1) the proposed inhibition of $\mathrm{Ca}^{2+}$ channels by a group II mGluR; and 2 ) the proposed 
presence of an inhibitor-1 protein in astrocytes. With regard to the first aspect, the inhibition of $\mathrm{Ca}^{2+}$ channels has been demonstrated in neurons as cited above, but not yet in astrocytes. However, we know that a $\mathrm{G}$ protein is necessary for the glutamate-stimulated increase in GFAP phosphorylation since the effect was reversed by the $G$ protein antagonist, pertussis toxin (72), as was the inhibition of $\mathrm{Ca}^{2+}$ currents in neurons by group II mGluRs (100). It is unlikely that primary astrocyte cultures will prove to be a useful model to investigate this problem since the expression of $\mathrm{Ca}^{2+}$ channels in these cells is dependent on a neuronal environment (111). Astrocytes co-cultured with neurons, confocal microscopy of astrocytes in situ and electrophysiology of acutely isolated astrocytes are possible approaches. In the case of the second aspect, we believe that the question of the occurrence of an inhibitor-1-like protein in hippocampal astrocytes remains open. The neuronal form of inhibitor- 1 was not detected by immunocytochemistry in astrocytes (112), but DARPP-32, a protein partly homologous to inhibitor-1 which also inhibits PP1 when phosphorylated, has been found in certain glial cells (113). It is possible that immuno- blotting (an approach which is more sensitive than immunocytochemistry) will provide more information.

The functional significance of the regulation of GFAP phosphorylation by glutamate in the immature hippocampus may be related to the narrow developmental window when the glutamate response is present. In the rat brain this window corresponds to the period of massive synaptogenesis during which astrocytes are known to proliferate. We have therefore speculated that glutamate released from developing synapses during this period may signal an increase in the phosphorylation state of GFAP and a consequent increase in the number of mitotic astrocytes (72). During subsequent development our evidence suggests that control by glutamate of GFAP phosphorylation and expression of the $\mathrm{Ca}^{2+}$-dependent dephosphorylation mechanism declines and that this control is absent in the adult hippocampus when astrocytes normally remain in interphase. A paper by Evans (114) reporting a $\mathrm{Ca}^{2+}$-dependent dephosphorylation of vimentin by cytosol prepared from mitotically selected cells, which was absent in cytosol from interphase cells, is particularly relevant to this hypothesis.

\section{References}

1. Tower DB (1988). Development of knowledge about astrocytes since Virchow. In: Norenberg MD, Hertz L \& Schousboe A (Editors), The Biochemical Pathology of Astrocytes. Alan Liss, New York, 3-18.

2. Travis J (1994). Glia: The brain's other cells. Science, 266: 970-972.

3. Kettenmann $H$ \& Ransom BR (Editors) (1995). Neuroglia. Oxford University Press, Oxford

4. Spacek J (1985). Three-dimensional analysis of dendritic spines. III. Glial sheath. Anatomical Embryology, 171: 245-252.

5. Bluemcke I, Eggli P \& Celio MR (1995). Relationship between astrocytic processes and "perineuronal nets" in rat neocortex. Glia, 15: 131-140.
6. Tsacopoulus M \& Magistretti PJ (1996). Metabolic coupling between glia and neurons. Journal of Neuroscience, 16: 877885.

7. Keyser DO \& Pellmar TC (1994). Synaptic transmission in the hippocampus: Critical role for glial cells. Glia, 10: 237-243.

8. Newman EA (1995). Glial cell regulation of extracellular potassium. In: Kettenmann $\mathrm{H}$ \& Ransom BR (Editors), Neuroglia. Oxford University Press, Oxford, 717-731.

9. Schousboe A \& Westergaard N (1995). Transport of neuroactive amino acids in astrocytes. In: Kettenmann H \& Ransom BR (Editors), Neuroglia. Oxford University Press, Oxford, 246-258.
10. Murphy S \& Pearce B (1987). Functional receptors for neurotransmitters on astroglial cells. Neuroscience, 22: 381-394.

11. McCarthy KD \& Salm AK (1991). Pharmacologically distinct subsets of astrocytes can be identified by their calcium response to neuroligands. Neuroscience, 41: 325-333.

12. Teichberg VI (1991). Glial glutamate receptors: likely actors in brain signalling FASEB Journal, 5: 3086-3091.

13. Hosli E \& Hosli L (1993). Receptors for neurotransmitters on astrocytes in the mammalian central nervous system. Progress in Neurobiology, 40: 477-506. 
14. Neary JT \& Zhu Q (1994). Signalling by ATP receptors in astrocytes. Neuroreport, 5: 1617-1620.

15. Kimelberg HK (1995). Receptors on astrocytes - What possible functions? Neurochemistry International, 26: 27-40.

16. Barres BA, Chun LLC \& Corey DP (1990). Ion channels in vertebrate glia. Annual Review of Neuroscience, 13: 441-474.

17. Sontheimer H \& Ritchie M (1995). Voltage-gated sodium and calcium channels in astrocytes. In: Kettenmann H \& Ransom BR (Editors), Neuroglia. Oxford University Press, Oxford, 202-220.

18. Seil FJ, Eckenstein FP \& Reier PJ (1992). Induction of dendrite spine proliferation by an astrocyte-secreted factor. Experimental Neurology, 60: 85-89.

19. Nicoletti $F$, Magri $G$, Ingrao F, Bruno $V$, Catania MV, Dell'Albani P, Condorelli DF \& Avola R (1990). Excitatory amino acids stimulate phospholipid hydrolysis and reduce proliferation in cultured astrocytes. Journal of Neurochemistry, 54: 771-777.

20. Dani JW \& Smith SJ (1995). The triggering of astrocytic calcium waves by NMDAinduced neuronal activation. In: Calcium Waves, Gradients and Oscillations, Ciba Foundation Symposium 188. Wiley, Chichester, UK.

21. Nedergaard M (1994). Direct signalling from astrocytes to neurons in cultures of mammalian brain cells. Science, 263: 1768-1771.

22. Hassinger TD, Atkinson PB, Strecker GJ, Whalen LR, Dudek FE, Kossel AH \& Kater SB (1995). Evidence for glutamate-mediated activation of hippocampal neurons by glial calcium waves. Journal of Neurobiology, 28: 159-170.

23. Porter JT \& McCarthy KD (1996). Hippocampal astrocytes respond to glutamate released from synaptic terminals. Journal of Neuroscience, 16: 5073-5081.

24. Canady KS \& Rubel EW (1992). Rapid and reversible astrocytic reaction to afferent blockade in chick cochlear nucleus. Journal of Neuroscience, 12: 1001-1009.

25. Georgiou J, Robitaille R, Trimble WS \& Charlton MP (1994). Synaptic regulation of glial protein expression in vivo. Neuron, 12: 443-455.

26. Shao Y \& McCarthy KD (1994). Plasticity of astrocytes. Glia, 11: 147-155.

27. Muller CM (1995). Glial cells and activitydependent central nervous system plasticity. In: Kettenmann H \& Ransom BR (Editors), Neuroglia. Oxford University Press, Oxford, 805-814.
28. Hawrylak N \& Greenough WT (1995). Monocular deprivation alters the morphology of glial fibrillary acidic protein-immunoreactive astrocytes in the rat visual cortex. Brain Research, 683: 187-199.

29. Hansen A, Jorgensen OS, Bolwig TG \& Barry DI (1991). Hippocampal kindling in the rat is associated with time-dependent increases in the concentration of glial fibrillary acidic protein. Journal of Neurochemistry, 57: 1716-1720.

30. Dalby NO, Rondouin G \& Lerner-Natoli M (1995). Increase in GAP-43 and GFAP immunoreactivity in the rat hippocampus subsequent to perforant path kindling. Journal of Neuroscience Research, 41: 613-619.

31. Kraig $R P$, Dong $L$, Thisted $R$ \& Jaeger $C B$ (1991). Spreading depression increases immunohistochemical staining of glial fibrillary acidic protein. Journal of Neuroscience, 11: 2187-2198.

32. Bonthius DJ, Stringer JL, Lothman EW \& Steward O (1994). Spreading depression and reverberatory seizures induce the up regulation of mRNA for glial fibrillary acidic protein. Brain Research, 645: 215-224.

33. Sirevaag AM \& Greenough WT (1991). Plasticity of GFAP-immunoreactive astrocytes: size and number in visual cortex of rats reared in complex environments. Brain Research, 540: 273-278.

34. Wenzel J, Lammert G, Meyer U \& Krug M (1991). The influence of long-term potentiation on the spatial relationship between astrocyte processes and potentiated synapses in the dentate gyrus neuropil of rat brain. Brain Research, 560: 122-131.

35. McCall MA, Gregg RG, Behringer RR, Brenner M, Delaney $C L$, Galbreath EJ, Zhang CL, Pearce RA, Chiu SY \& Messing A (1996). Targeted deletion in astrocyte intermediate filament (Gfap) alters neuronal physiology. Proceedings of the National Academy of Sciences, USA, 93: 6361-6366

36. Hatten ME, Liem RKH, Shelanski ML \& Mason CA (1991). Astroglia in CNS injury. Glia, 4: 233-243.

37. Steward O (1994). Electroconvulsive seizures upregulate astroglial gene expression selectively in the dentate gyrus. Molecular Brain Research, 25: 217-224.

38. Rocha E \& Rodnight R (1994). Chronic administration of lithium chloride increases immunodetectable glial fibrillary acidic protein in the rat hippocampus. Journal of Neurochemistry, 63: 15821584.
39. Bradbury EJ, Kershaw TR, Marchbanks RM \& Sinden JD (1995). Astrocyte transplants alleviate lesion induced memory deficits independently of cholinergic recovery. Neuroscience, 65: 955-972.

40. Eng LF (1985). Glial fibrillary acidic protein (GFAP): the major protein of glial intermediate filaments in differentiated astrocytes. Journal of Neuroimmunology, 8: 203-214.

41. Steinert PM \& Roop DR (1988). Molecular and cellular biology of intermediate filaments. Annual Review of Biochemistry, 57: 593-625.

42. Shoeman RL \& Traub P (1993). Assembly of intermediate filaments. Bioessays, 15: 605-611.

43. Geisler N, Schunemann J \& Weber K (1992). Chemical cross-linking indicates a staggered and antiparallel protofilament of desmin intermediate filaments and characterizes one higher-level complex between protofilaments. European Journal of Biochemistry, 206: 841-852.

44. Chen W-J \& Liem RKH (1994). The endless story of the glial fibrillary acidic protein. Journal of Cell Biology, 107: 22992311.

45. Eriksson JE, Brautigan DL, Vallee $R$, Olmstead J, Fujiki $H$ \& Goldman RD (1992). Cytoskeletal integrity in interphase cells requires protein phosphatase activity. Proceedings of the National Academy of Sciences, USA, 89: 11093-11097.

46. Nakamura $Y$, Takeda $M$, Angelides KJ, Tada K, Hariguchi S \& Nishimura T (1991). Assembly, disassembly, and exchange of glial fibrillary acidic protein. Glia, 4: 101110

47. Inagaki $M$, Nakamura $Y$, Takeda $M$, Nishimura T \& Inagaki N (1994). Glial fibrillary acidic protein: Dynamic property and regulation by phosphorylation. Brain $\mathrm{Pa}$ thology, 4: 239-243.

48. Nichol ID \& Quinlan RA (1994). Chaperone activity of $\alpha$-crystallins modulates intermediate filament assembly. EMBO Journal, 13: 945-953.

49. Bianchi R, Giambanco I \& Donato R (1993). S100 protein but not calmodulin binds to the glial fibrillary acidic protein and inhibits its polymerization in a $\mathrm{Ca}^{2+}$ dependent manner. Journal of Biological Chemistry, 268: 12669-12674.

50. Sarria AJ, Nordeen SK \& Evans RM (1990). Regulated expression of vimentin cDNA in cells in the presence and absence of a pre-existing vimentin filament network. Journal of Cell Biology, 120: 1251-1281. 
51. Vikstrom KL, Lim S-S, Goldman RD \& Borisy GG (1992). Steady state dynamics of intermediate filament networks. Journal of Cell Biology, 118: 121-129.

52. McCarthy KD, Salm A \& Lerea LS (1988). Astroglial receptors and their regulation of intermediate filament protein phosphorylation. In: Kimelberg HK (Editor), Glial Cell Receptors. Raven Press, New York, 1-22.

53. Harrison B \& Mobley PL (1989). Protein phosphorylation in astrocytes mediated by protein kinase C. Comparison with phosphorylation by cyclic AMP-dependent protein kinase. Journal of Neurochemistry, 53: 1245-1251.

54. Tsujimura K, Tanaka J, Ando S, Matsuoka Y, Kusubata M, Sugiura H, Yamauchi T \& Inagaki M (1994). Identification of phosphorylation sites on glial fibrillary acidic protein for cdc2 kinase and $\mathrm{Ca}^{2+}{ }^{2+}$-calmodulin-dependent protein kinase II. Journal of Biochemistry, 116: 426-434.

55. Feinstein DL, Weinmaster GA \& Milner RJ (1992). Isolation of cDNA clones encoding glial fibrillary acidic protein: expression in astrocytes and in Schwann cells. Journal of Neuroscience Research, 32: 114.

56. Nishizawa K, Yano T, Shibata M, Ando S, Takahashi T \& Inagaki M (1991). Specific localization of phosphointermediate filament protein in the constricted area of dividing cells. Journal of Biological Chemistry, 266: 3074-3079.

57. Sekimata M, Tsujimura K, Tanaka J, Takeuchi Y, Inagaki N \& Inagaki M (1996). Detection of protein kinase activity specifically activated at metaphase anaphase transition. Journal of Cell Biology, 132: 635-641.

58. Inagaki M, Matsuoka Y, Tsujimura K, Ando S, Tokui T, Takahashi T \& Inagaki N (1996). Dynamic property of intermediate filaments: Regulation by phosphorylation. Bioessays, 18: 481-487.

59. Leal RB (1995). Estudo do sistema fosforilante da ppH47/GFAP em cérebro de ratos: distribução regional, identificação das quinases envolvidas e mapeamento fosfopeptidico. Doctoral thesis, Universidade Federal do Paraná.

60. Yano S, Fukunaga K, Ushio Y \& Miyamoto E (1994). Activation of $\mathrm{Ca}^{2+} /$ calmodulindependent protein kinase II and phosphorylation of intermediate filament proteins by stimulation of glutamate receptors in cultured rat cortical astrocytes. Journal of Biological Chemistry, 269: 5428-5439.
61. Ando S, Tanabe K, Gona Y, Sato C \& Inagaki M (1989). Domain- and sequencespecific phosphorylation of vimentin induces disassembly of the filament structure. Biochemistry, 28: 2974-2979.

62. Nakamura $Y$, Takeda $M$ \& Nishimura $T$ (1996). Dynamics of bovine glial fibrillary acidic protein phosphorylation. Neuroscience Letters, 205: 91-94.

63. Chou Y-H, Bischoff JR, Beach D \& Goldman RD (1990). Intermediate filament reorganization during mitosis is mediated by $\mathrm{p} 34 \mathrm{cdc} 2$ phosphorylation of vimentin. Cell, 62: 1063-1071.

64. Chou YH, Opal P, Quinlan RA \& Goldman RD (1996). The relative roles of specific $N$ and $\mathrm{C}$-terminal phosphorylation sites in the disassembly of intermediate filament in mitotic BHK-21 cells. Journal of Cell Science, 109: 817-826.

65. Matsuoka Y, Nishizawa K, Yano T, Shibata $M$, Ando $S$, Takahashi $T$ \& Inagaki $M$ (1993). Two different protein kinases act on a different time schedule as glial filament kinases during mitosis. EMBO Journal, 11: 2895-2902.

66. Eriksson JE, Opal P \& Goldman RD (1992). Intermediate filament dynamics. Current Opinion in Cell Biology, 4: 99-104.

67. Lee W-C, Yu J-S, Yang S-D \& Lai Y-K (1992). Reversible hyperphosphorylation and reorganisation of vimentin intermediate filaments by okadaic acid in $9 \mathrm{~L}$ rat brain tumour cells. Journal of Cellular Biochemistry, 49: 378-393.

68. Ho DT \& Roberge M (1996). The antitumor drug fostriecin induces vimentin hyperphosphorylation and intermediate filament reorganization. Carcinogenesis, 17: 967-972.

69. Wofchuk ST \& Rodnight R (1990). Stimulation by glutamate of the phosphorylation of two substrates of protein kinase $\mathrm{C}$, B-50/GAP and MARCKS, and of ppH-47, a protein highly labelled in incubated slices from the hippocampus. Neuroscience Research Communications, 6: 135-140.

70. Gonçalves CA \& Rodnight R (1992). Apparent identity of $\mathrm{ppH}-47$, a protein highly phosphorylated in the hippocampus with a form of glial fibrillary acidic protein. Neuroscience Research Communications, 11: 109-117.

71. Nakanishi S \& Masu M (1994). Molecular diversity and functions of glutamate receptors. Annual Review of Biophysics and Biomolecular Structure, 23: 319-348.
72. Wofchuk ST \& Rodnight R (1994). Glutamate stimulates the phosphorylation of glial fibrillary acidic protein in slices of immature hippocampus via a metabotropic receptor. Neurochemistry International, 24: 517-523.

73. Wofchuk ST \& Rodnight R (1995). Agedependent changes in the regulation by external calcium ions of the phosphorylation of glial fibrillary acidic protein in slices of rat hippocampus. Developmental Brain Research, 85: 181-186.

74. Cull-Candy SG \& Wyllie DJA (1991). Glutamate-receptor channels in mammalian glial cells. Annals of the New York Academy of Sciences, 633: 458-474.

75. Gallo V \& Russell JT (1995). Excitatory amino acid receptors in glia: Different subtypes for distinct functions? Journal of Neuroscience Research, 42: 1-8.

76. Hansson E \& Ronnback L (1995). Astrocytes in glutamate transmission. FASEB Journal, 9: 343-350.

77. Conti F, DeBiasi S, Minelli A \& Melone M (1996). Expression of NR1 and NR2A/B subunits of the NMDA receptor in cortical astrocytes. Glia, 17: 254-258.

78. Steinhäuser C \& Gallo V (1996). News of glutamate receptors in glial cells. Trends in Neurosciences, 19: 339-345.

79. Aramori I \& Nakashini S (1992). Signal transduction and pharmacological characteristics of a metabotropic glutamate receptor, mGluR1, in transfected $\mathrm{CHO}$ cells. Neuron, 8: 757-765.

80. Abe T, Sugihara $H$, Nawa $H$, Shigemoto $R$, Mizuno N \& Nakanishi S (1992). Molecular characterization of a novel metabotropic glutamate receptor mGluR5 coupled to inositol phosphate/ $\mathrm{Ca}^{2+}$ signal transduction. Journal of Biological Chemistry, 267: 13361-13368.

81. Tanabe Y, Nomura A, Masu M, Shigemoto R, Mizuno N \& Nakashini S (1993). Signal transduction, pharmacological properties, and expression of patterns of two rat metabotropic glutamate receptors, mGluR3 and mGluR4. Journal of Neuroscience, 13: 1372-1378.

82. Kim WT, Rioult MG \& Cornell-Bell $A H$ (1994). Glutamate-induced calcium signaling in astrocytes. Glia, 11: 173-184.

83. Porter JT \& McCarthy KD (1995). GFAPpositive hippocampal astrocytes in situ respond to glutamatergic neuroligands with increases in $\left[\mathrm{Ca}^{2+}\right]$ i. Glia, 13: 101112. 
84. Romano C, Sesma MA, MacDonald C, O'Malley K, van den Pol AN \& Olney JW (1995). Distribution of metabotropic receptor mGluR5 immunoreactivity in the rat brain. Journal of Comparative Neurology, 355: 455-469.

85. Ohishi H, Shigemoto R, Nakanishi S \& Mizuno N (1993). Distribution of the messenger RNA for a metabotropic glutamate receptor (mGluR3) in the rat brain an in situ hybridization study. Journal of Comparative Neurology, 335: 252-266.

86. Thompson AK, Mostafapour SP, Denlinger LC, Bleasdale JE \& Fisher SK (1991). The aminosteroid U-73122 inhibits muscarinic receptor sequestration and phosphoinositide hydrolysis in SK-N-SH neuroblastoma cells. Journal of Biological Chemistry, 266: 23856-23862.

87. Verkhratsky A \& Kettenmann H (1996). Calcium signalling in glial cells. Trends in Neurosciences, 19: 346-352.

88. Glaum SR, Holzwarth JA \& Miller RJ (1990). Glutamate receptors activate $\mathrm{Ca}^{2+}$ mobilization and $\mathrm{Ca}^{2+}$ influx into astrocytes. Proceedings of the National Academy of Sciences, USA, 87: 34543458.

89. Ahmed Z, Lewis CA \& Faber DS (1990). Glutamate stimulates release of $\mathrm{Ca}^{2+}$ from internal stores in astroglia. Brain Research, 516: 165-169.

90. Cornell-Bell AH \& Finkbeiner SM (1991). $\mathrm{Ca}^{2+}$ waves in astrocytes. Cell Calcium, 12: 185-204

91. Finkbeiner SM (1993). Glial calcium. Glia, 9: 83-104.

92. Duffy S \& MacVicar BA (1995). Adrenergic calcium signaling in astrocyte networks within the hippocampal slice. Journal of Neuroscience, 15: 5535-5550.

93. Charles AC, Merrill JE, Dirksen ER \& Sanderson MJ (1991). Intracellular signalling in glial cells: calcium waves and oscillations in response to mechanical stimulation and glutamate. Neuron, 6: 983-992.

94. Sanderson MJ, Charles AC, Boitano S \& Dirksen ER (1994). Mechanisms and function of intercellular calcium signalling. Molecular and Cellular Endocrinology, 98: 173-187.

95. Glaume C \& McCarthy KD (1996). Control of gap-junctional communication in astrocytic networks. Trends in Neurosciences, 19: 319-325.

96. Parpura V, Basarsky TA, Liu F, Jeftinija K, Jeftinija S \& Haydon PG (1994). Glutamate-mediated astrocyte-neuron signalling. Nature, 369: 744-747.
97. Hille B (1994). Modulation of ion-channel function by G-protein-coupled receptors. Trends in Neurosciences, 17: 531-536.

98. Wickham KD \& Clapham DE (1995). Gprotein regulation of ion channels. Current Opinion in Neurobiology, 5: 278-285.

99. Sayer RJ, Schwindt PC \& Crill WE (1992). Metabotropic glutamate receptor-mediated suppression of L-type calcium current in acutely isolated neocortical neurons. Journal of Neurophysiology, 68: 833-842.

100. Chavis $P$, Shinozaki H, Bockaert J \& Fagni $L$ (1994). The metabotropic receptor types 2/3 inhibit L-type calcium channels via a pertussis toxin-sensitive G-protein in cultured cerebellar granule cells. Journal of Neuroscience, 14: 7067-7076.

101. Herlitze S, Garcia DE, Mackie K, Hille B, Scheuer T \& Catterall WA (1996). Modulation of $\mathrm{Ca}^{2+}$ channels by $\mathrm{G}$ protein $\mathrm{B} \gamma$ subunits. Nature, 380: 258-262.

102. Stemmer P \& Klee CB (1991). Serine/ threonine phosphatases in the nervous system. Current Opinion in Neurobiology, 1: 53-64.

103. Vinadé L \& Rodnight R (1996). The dephosphorylation of glial fibrillary acidic protein (GFAP) in the immature rat hippocampus is catalyzed mainly by a type 1 protein phosphatase. Brain Research, 732: 195-200

104. Liu J, Farmer Jr JD, Lane WS, Friedman J, Weissman I \& Schreiber SL (1991). Calcineurin is a common target of cyclophylin-cyclosporin A and FKBP-FK506 complexes. Cell, 66: 807-815.

105. Matsui H, Doi A, Itano $T$, Shimada $M$, Wang JH \& Hatase O (1987). Immunohistochemical localization of calcineurin, a calmodulin-stimulated phosphatase, in the rat hippocampus using a monoclonal antibody. Brain Research, 402: 193-196.

106. Goto S, Yamada K, Oyama T, Korematsu K, Nagahiro S, Ushio Y, Fukunaga K, Miyamoto E \& Hofer W (1994). Cellular localization of type II $\mathrm{Ca}^{2+} /$ calmodulin-dependent protein kinase in the rat basal ganglia and intrastriatal grafts derived from fetal striatal primordia, in comparison with that of $\mathrm{Ca}^{2+} /$ calmodulin-regulated protein phosphatase, calcineurin. Neuroscience, 62: 695-705.

107. Mulkey RM, Endo S, Shenolikar S \& Malenka RC (1994). Involvement of a calcineurin/inhibitor-1 phosphatase cascade in hippocampal long-term depression. Nature, 369: 486-488.

108. Cohen P (1989). The structure and regulation of protein phosphatases. Annual Review of Biochemistry, 58: 453-508.
109. Mukherji S \& Soderling TR (1994). Regulation of $\mathrm{Ca}^{2+} /$ calmodulin-dependent protein kinase II by inter- and intrasubunitcatalyzed autophosphorylations. Journal of Biological Chemistry, 269: 1374413747.

110. Nixdorf-Bergweiler BE, Albrecht D \& Heinemann U (1994). Developmental changes in the number, size, and orientation of GFAP-positive cells in the CA1 region of rat hippocampus. Glia, 12: 180195.

111. Corvalan V, Cole R, de Vellis J \& Hagiwara S (1990). Neuronal modulation of calcium channel activity in cultured rat astrocytes. Proceedings of the National Academy of Sciences, USA, 87: 43454348.

112. Gustafson EL, Girault J-A, Hemmings Jr HC, Nairn AC \& Greengard P (1991). Immunocytochemical localization of phosphatase inhibitor- 1 in rat brain. Journal of Comparative Neurology, 310: 170-188.

113. Ouimet CC, Miller PE, Hemmings HC, Walaas SI \& Greengard P (1984). DARPP32, a dopamine- and adenosine $3^{\prime}: 5^{\prime}$ monophosphate-regulated phosphoprotein enriched in dopamine-innervated brain regions. III. Immunocytochemical localization. Journal of Neuroscience, 4 111-124.

114. Evans RM (1989). Phosphorylation of vimentin in mitotically selected cells. In vitro cyclic AMP-dependent and calciumstimulated phosphatase activities. Journal of Cell Biology, 108: 67-78.

115. Schoepp DD \& Johnson BG (1993). Pharmacology of metabotropic glutamate receptor inhibition of cyclic AMP formation in the adult rat hippocampus. Neurochemistry International, 22: 277-283

116. Schoepp DD \& Johnson BG (1993). Metabotropic glutamate receptor modulation of cAMP accumulation in the neonatal rat hippocampus. Neuropharmacology, 32: 1359-1365.

117. Schoepp DD \& Conn PJ (1993). Metabotropic glutamate receptors in brain function and pathology. Trends in Pharmacological Sciences, 14: 13-20.

118. Pin J-P \& Duvoisin R (1995). The metabotropic glutamate receptors: Structure and functions. Neuropharmacology, 34: 1-26.

119. Nicoletti F, Bruno V, Copani A, Casabona G \& Knopfel T (1996). Metabotropic glutamate receptors: a new target for the therapy of neurodegenerative disorders. Trends in Neurosciences, 19: 267-271. 